\title{
Kebijakan Dan Praktek Kemitraan Era Orde Baru Serta Rekonstruksi Kebijakan Era Reformasi Di Indonesia
}

\author{
Yanto Sufriadi \\ Fakultas Hukum Universitas Prof. Dr. Hazairin, SH Bengkulu Indonesia \\ Jln. Ahmad Yani No. 1 Kota Bengkulu, 38115, Indonesia \\ yanto@yantosufriadi.com
}

Received: 4 Desember 2020; Accepted: 24 Agustus 2021; Published: 31 Januari 2022

DOI: 10.20885/iustum.vol29.iss1.art7

\begin{abstract}
This study focuses on the partnership policies and practices in the investment in plantation sub-sector in New Order Era and the reconstruction of reform policies in Indonesia. This study aims to explain partnership policies and practices in the investment in New Order Era in Indonesia, and the reconstruction of the Reform Era partnership policies. This research was conducted by using empirical legal research methods with a case study approach. Primary data was obtained from interviews with Plasma Farmers in the Plantation Sub-sector in Bengkulu, and secondary data was obtained from literature studies sourced from books, joumals and laws and regulations. This study concludes that: (1). The New Order Partnership Policy in Indonesia was not intended to implement the principle of joint effort in Article 33 of the 1945 Constitution, but in the context of implementing the World Bank and IMF projects since 1976, which were later established as investment policies in 1995; (2). The practice of the Nuclear-Plasma partnership in the Plantation Sub-sector during the New Order placed Plasma companies under the Subordination of the Core Company and lacked protection from the Government, resulting in an exploitative pattern of economic relations; and (3). Reconstruction of the Reform Era's Partnership Policy is carried out by providing ease of business licensing, legal protection, and empowerment of Cooperatives, Micro Enterprises, and Small Businesses, as well as continuous monitoring of partnerships.
\end{abstract}

Key Words: Exploitative; the new order Era; reform era; partnership policy; investment

\section{Abstrak}

Kajian ini berfokus pada kebijakan dan praktik kemitraan dalam investasi subsektor perkebunan di Era Orde Baru dan rekonstruksi kebijakan Era Reformasi di Indonesia. Penelitian ini bertujuan untuk menjelaskan kebijakan dan praktik kemitraan dalam investasi Era Orde Baru di Indonesia, dan rekonstruksi kebijakan kemitraan Era Reformasi. Penelitian ini dilakukan menggunakan metode penelitian hukum empiris dengan pendekatan studi kasus. Data primer diperoleh dari wawancara dengan Petani Plasma Subsektor Perkebunan di Bengkulu, dan data sekunder diperoleh dari studi literatur yang bersumber dari buku, jurnal dan peraturan perundang-undangan. Penelitian ini menyimpulkan bahwa: (1). Kebijakan Kemitraan Orde Baru di Indonesia tidak dimaksudkan untuk melaksanakan prinsip usaha bersama dalam Pasal 33 UUD 1945, tetapi dalam rangka pelaksanaan proyek Bank Dunia dan IMF sejak tahun 1976, yang kemudian ditetapkan sebagai kebijakan investasi, pada tahun 1995; (2). Praktek kemitraan Inti-Plasma Subsektor Perkebunan pada masa Orde Baru menempatkan perusahaan Plasma di bawah Subordinasi Perusahaan Inti dan kurang memperoleh perlindungan dari Pemerintah, sehingga terjadi pola hubungan ekonomi yang eksploitatif; dan (3). Rekonstruksi Kebijakan Kemitraan Era Reformasi dilakukan dengan memberikan kemudahan perizinan berusaha, perlindungan hukum, dan pemberdayaan Koperasi, Usaha Mikro, dan Usaha Kecil, serta pemantauan kemitraan secara berkesinambungan.

Kata-kata Kunci: Eksploitatif; era orde baru; era reformasi; kebijakan kemitraan; penenaman modal 


\section{Pendahuluan}

Kesenjangan struktur ekonomi nasional yang muncul sebagai akibat kebijaksanaan pembangunan ekonomi nasional pada paruh pertama Pemerintahan Orde Baru di Indonesia (1967-1977), ternyata telah mendorong lahirnya konsep pemikiran baru tentang model pembangunan ekonomi nasional Pemerintahan Orde Baru Indonesia pada periode berikutnya.

Semula, paradigma pembangunan ekonomi berdasarkan pertumbuhan dan modernisasi, yang berasal dari pemikiran Kaum Neo-Klasik; yang diprakarsai oleh Solow, berpendapat bahwa teknologi dapat dianggap sebagai faktor yang eksogen yang datang dari luar sistem ke dalam proses produksi. Siapapun atau negara manapun mempunyai kesempatan yang sama untuk memanfaatkan teknologi dengan pengeluaran rendah atau tanpa biaya sama sekali. Pandangan ini didasarkan pada asumsi bahwa dalam perekonomian yang terbuka, yang semua faktor produksinya dapat berpindah secara leluasa serta informasi dan teknologi dapat dimanfaatkan oleh setiap negara, maka dengan sendirinya pertumbuhan semua negara di dunia akan konvergen, dan itu berarti kesenjangan akan berkurang. ${ }^{1}$ Tetapi dalam perkembangannya konvergensi yang diharapkan itu ternyata tidak pernah terjadi. Sebaliknya, kesenjangan antara negara maju dan negara berkembang semakin melebar. ${ }^{2}$

Kenyataan tersebut memunculkan pemikiran lain, yaitu pertumbuhan endogen. Inti pola pikir ini adalah bahwa pertumbuhan ekonomi dan kemajuan serta dinamika ekonomi bersumber dari dalam sistem sendiri dan unsur endogen tersebut mewujudkan diri dalam efisiensi dan produktivitas. Semakin besar peran efisiensi dan produktivitas sebagai sumber pertumbuhan, semakin besar pula unsur kekuatan (daya) pembangunan dari dalam. ${ }^{3}$

Sumber pertumbuhan dalam teori endogen; yang antara lain dikembangkan oleh Romer adalah meningkatnya aliran informasi serta stok pengetahuan dan ide baru dalam perekonomian yang mendorong tumbuhnya daya cipta dan inisiatif

1 Muslimin Nasution, "Pembangunan Sumberdaya Manusia dan Ekonomi Berbasis Pertanian dan Kelautan Untuk Memperkuat Otonomi Daerah Menuju Masyarakat Madani Indonesia”, Makalah, Simposium Nasional Pembangunan SDM, OTDA dan Masyarakat Madani Indonesia, Forum Mahasiswa Pascasarjana IPB Bogor, 17 Febuari 2001.

${ }^{2}$ Budi Winarno, Globalisasi \& Krisis Demokrasi, PT Buku Kita, Jakarta, 2007, hlm. 74

${ }^{3}$ Loc. Cit. 
yang diwujudkan dalam kegiatan inovatif dan produktif. Teori endogen ini didasarkan pada berbagai premis pokok antara lain, bahwa pasar tidak sempurna dan eksternalitas dalam perekonomian. Teknologi atau temuan-temuan baru memberikan eksternalitas bagi perekonomian. ${ }^{4} \mathrm{Di}$ samping itu, pengembangan teori pertumbuhan endogen tersebut, memberikan perhatian yang lebih besar pada pembangunan manusia dalam pembangunan ekonomi. Hal itu didasarkan pada pemikiran bahwa pengetahuan baru dan keterampilan terkandung di dalam Sumber Daya Manusia (SDM), dan pembangunan ekonomi tergantung pada peningkatan teknologi, pengetahuan dan cara-cara baru dalam proses produksi.

Pemberdayaan (empowerment) rakyat dalam konteks perekonomian adalah membangun kekuatan dari dalam sistem ekonomi sendiri. Dengan demikian pemberdayaan ekonomi kerakyatan dapat diartikan sebagai konsep pembangunan ekonomi yang berorientasi pada upaya mensejahterakan rakyat banyak, berdasarkan kekuatan sendiri; yang dapat diperkuat dari unsur dari luar.

Berdasarkan konsep pemberdayaan ekonomi kerakyatan tersebut, maka bererapa kebijaksanaan strategis dibidang penanaman modal; yang diharapkan dapat mendorong terjadinya perubahan struktur ekonomi dan kultural, diantaranya adalah : memberikan prioritas pengalokasian sumber daya kepada bidang-bidang usaha produktif dimana bagian terbesar massa rakyat melakukan usaha di bidang tersebut serta pada bidang usaha potensial dengan memanfaatkan sumber kekayaan alam yang tersedia.

Di Indonesia Sektor pertanian merupakan bidang yang paling banyak diusahakan oleh rakyat. Pertanian dalam arti luas yaitu pertanian yang mencakup perkebunan, kehutanan, peternakan dan perikanan sedangkan pertanian dalam arti luas yaitu pertanian rakyat. ${ }^{5}$ Sub Sektor Perkebunan merupakan salah satu bidang usaha potensial yang layak dijadikan prioritas dalam Penanaman Modal; mengingat ketersediaan daya dukung alam dan massa rakyat terbesar yang menggantungkan sumber penghidupannya dari sub sektor usaha ini.

Dalam menghadapi sistem perekonomian global yang bertumpu pada persaingan pasar, hendaknya tidak diikuti pula dengan melakukan persaingan

\footnotetext{
${ }^{4}$ Ibid.

5 Achmad Afif Rudiyanto, "Pola Kemitraan Koperasi Sejahtera Abadi dalam Meningkatkan Keuntungan Petani Cabai”, JEJAK (Journal of Economics and Policy), Vol. 7 No 2, September 2014, hlm. 176
} 
diantara sesama pelaku ekonomi nasional sendiri, melainkan justeru harus memperkokoh kebersamaan untuk menghadapi mekenisme pasar global tersebut. Berangkat dari nilai-nilai (prinsip) kebersamaan yang digariskan dalam Pasal 33 Undang-Undang Dasar Negara Kesatuan Republik Indonesia 1945, maka Kemitraan Usaha dalam kebijaksanaan investasi seharusnya semakin dikembangkan.

Kemitraan Usaha dalam kebijaksanaan investasi, bukan saja penting sebagai upaya untuk pemerataan ekonomi dan memacu pertumbuhan ekonomi nasional, tetapi juga penting untuk menghadapi persaingan perekonomian global. Kecenderungan global dinegara-negara maju dengan sistem ekonomi liberal pun, sekarang ini, bahkan telah ditandai oleh munculnya berbagai aliansi ekonomi; seperti negara-negara Eropa dengan Masyarakat Ekonomi Eropa (MEE)-nya. Aliansi yang seperti itu, sesungguhnya identik dengan strategi kemitraan, yang diarahkan untuk mernghadapi persaingan ekonomi global.

Menghadapi persaingan dalam perekonomian global yang demikian, maka penelitian terhadap kemitraan di Indonesia menjadi sangat penting untuk dilakukan, mulai dari kebijakan dan praktek kemitraan Era Pemerintahan Orde Baru maupun terhadap rekonstruksi Kebijakan kemitraan yang dilakukan dalam Era Pemerintahan Reformasi sekarang ini, dengan memperhatikan pengalaman pada Era Pemerintahan Orde Baru.

\section{Rumusan Masalah}

Berdasarkan uraian yang dikemukakan di atas, tulisan ini difokuskan untuk menjawab pertanyaan sebagai berikut : pertama, bagaimana kebijakan kemitraan usaha dalam penanaman modal pada era orde baru di Indonesia? Kedua, bagaimana praktek kemitraan usaha dalam penanaman modal sub-sektor perkebunan di Provinsi Bengkulu pada masa orde baru? Ketiga, bagaimana rekonstruksi kebijakan kemitraan dalam penanaman modal era reformasi di Indonesia?

\section{Tujuan Penelitian}

Penelitian ini bertujuan untuk mengetahui pertama, kebijakan kemitraan usaha dalam penanaman modal pada era orde baru di Indonesia. Kedua, praktek kemitraan usaha dalam penanaman modal sub-sektor perkebunan di Provinsi 
Bengkulu pada masa orde baru. Ketiga, rekonstruksi kebijakan kemitraan dalam penanaman modal era reformasi di Indonesia.

\section{Metode Penelitian}

Metode yang digunakan dalam studi ini termasuk dalam jenis penelitian hukum emperis dengan menggunakan pendekatan kasus. Data Primer diperoleh dari hasil wawancara dalam penelitian lapangan terhadap kasus praktek kemitraan subsektor perkebunan di provinsi bengkulu era orde baru. Pemilihan lokasi penelitian dilakukan dengan pertimbangan karena di daerah ini masih banyak petani plasma yang melakukan kemitraan dengan perusahaan besar pada awal pertama kali pola kemitraan dipraktekkan di Indonesia. Data skunder diperoleh dari penelitian pustaka, yang bersumber dari buku, jurnal dan peraturan perundangundangan. Data yang diperoleh diolah dan dianalisis secara kualitatif.

\section{Hasil Penelitian dan Pembahasan}

\section{Kebijakan Kemitraan Era Orde Baru di Indonesia}

Pola Kemitraan Usaha di Indonesia untuk pertama kalinya dilakukan pada Subsektor perkebunan; berkaitan dengan proyek bantuan Bank Dunia untuk perkebunan skala besar dengan pola Nucleus Estate and Smallholder (NES), yang kemudian disebut Perusahaan Inti Rakyat Perkebunan (PIR-Bun), yaitu suatu pola pengembangan perkebunan dengan mempergunakan perkebunan besar sebagai Inti dan Perkebunan Rakyat disekitarnya sebagai Plasma. Pembangunan perkebunan di Indonesia sudah berlangsung sejak 1973-1974 yang dilakukan dengan mengitegrasikan program transmigrasi dengan program Perkebunan Inti Rakyat (PIR). ${ }^{6}$ Komoditas perkebunan yang diusahakan dengan Pola PIR-Bun meliputi 7 jenis komoditas, yaitu : kelapa sawit, kelapa hibrida, karet, tebu, kapas dan kakao (coklat).

Perkebunan Kelapa Sawit dan Karet mulai diperkenalkan dalam bentuk proyek NES/PIR-Bun pada 1977/1978, dan sejak 1984 pengembangan 
perkebunan Kelapa Sawit dan Karet dilakukan dengan pola PIR.7 Selanjutnya, sejak tahun 1986 PIR-Bun Kelapa Sawit dan Karet baik yang dilakukan oleh Perusahaan Negara (PTP/PNP) maupun oleh Perusahaan Besar Swasta Nasional / Asing (PBSN/PBSA); dikaitkan dengan program transmigrasi (PIR-Trans). ${ }^{8}$

Berdasarkan sumber dana investasi dan Petani yang menjadi plasmanya, PIR-Bun dibedakan menjadi : Proyek PIR lokal, Proyek PIR Khusus, Proyek PIR Bank Dunia/ ADB (NES I/II) dan Proyek PIR Transmigrasi. Tujuan pembangunan proyek PIR antara lain : membantu meningkatkan pendapatan petani sekaligus pemerataan pembangunan dan hasil-hasilnya, memperluas dan menciptakan lapangan kerja, memenuhi kebutuhan bahan baku industri dalam negeri dan pelestarian sumber daya dan lingkungan. Perusahaan perkebunan milik Pemerintah, selain tujuan tersebut, juga bertugas memberikan bantuan pelayanan bagi masyarakat petani melalui proses alih teknologi. ${ }^{9}$

Penerapan prinsip kemitraan yang telah dilaksanakan pada subsektor perkebunan tersebut, diperluas, dan dijadikan kebijaksanaan penanaman modal pada bidang usaha unggulan; yaitu bidang usaha yang prospektif dan harus memberikan nilai tambah, memiliki jangka waktu pengembalian modal yang relatif cepat, memiliki asset atau omzet tertentu serta memiliki keterkaitan dengan usaha hulu dan usaha hilir. ${ }^{10}$ Pada bagian konsideran SKB kedua menteri tersebut, dikemukakan bahwa kemitraan antara Usaha Besar Menengah pada bidang usaha unggulan tersebut, dimaksudkan sebagai upaya untuk memberikan bantuan dan kekuatan terhadap Usaha Kecil dan Koperasi yang memiliki kemampuan berkembang pada bidang usaha unggulan, dan kemitraan dilakukan

\footnotetext{
7 Keputusan Menteri Pertanian Nomor 853 Tahun 1984 tentang pengembangan perkebunan Kelapa Sawit dan Karet dilakukan dengan pola PIR.

8 Instruksi Presiden Nomor 1 Tahun 1986 tentang Pengembangan Perkebunan Dengan Pola Perusahaan Inti Rakyat Yang Dirkaitkan Dengan Program Transmigrasi dan Keputusan Menteri Pertanian Nomor .333/KPTS/KB/510/ 6/1986 Tentang Tata Cara Pelaksanaan Pengembangan Perkebunan Dengan Pola Pir Trans

9 Keputusan Menteri Pertanian Nomor 853 Tahun 1984 tentang pengembangan perkebunan Kelapa Sawit dan Karet dilakukan dengan pola PIR, Instruksi Presiden Nomor 1 tahun 1986 Tentang Pengembangan Perkebunan Dengan Pola Perusahaan Inti Rakyat Yang Dirkaitkan Dengan Program Transmigrasi dan Keputusan Menteri Pertanian Nomor .333/KPTS/KB/510/ 6/1986 tentang Tata Cara Pelaksanaan Pengembangan Perkebunan Dengan Pola Pir - Trans

${ }^{10}$ Keputusan Bersama Menteri Koperasi dan Pembinaan Pengusaha Kecil dan Menteri Negara Penggerak Dana Investasi/Ketua Badan Koordinasi Penanaman Modal Nomor 01/SKB/M/VI/1995 dan Nomor 11/SK/1995 tentang Penanaman Modal Dalam Bidang Usaha Unggulan Melalui Kemitraan Pengusaha Menengah dan Besar Dengan Pengusaha Kecil dan Koperasi.
} 
dalam keterkaitan antara usaha hulu dengan usaha hilir dengan prinsip saling memerlukan, saling memperkuat dan saling menguntungkan dengan disertai bantuan dan perkuatan oleh Pengusaha Menengah atau Pengusaha Besar, guna mengantisipasi kecenderungan relokasi industri dari negara-negara maju serta untuk memperkuat struktur perekonomian nasional.

Dalam SKB kedua Menteri tersebut, kemitraan diformulasikan sebagai kerja sama usaha antara Pengusaha Kecil dan Koperasi yang bergerak pada Usaha hulu dalam bidang usaha yang dicadangkan untuk Usaha Kecil dan Pengusaha Besar Menengah yang bergerak pada Usaha hilir. Usaha Besar Menengah memberikan bantuan dan perkuatan kepada Usaha Kecil dan Koperasi, dalam bentuk permodalan dan bantuan teknologi, dan kemudian produk yang dihasilkan oleh Usaha Kecil dan Koperasi, ditingkatkan nilai tambahnya oleh Usaha Besar Menengah. Selain itu, untuk bidang usaha unggulan yang tidak termasuk bidang usaha yang dicadangkan bagi Usaha Kecil dan Koperasi, kemitraan diformulasikan berupa penyertaan modal saham (equity) Usaha Kecil dan atau Koperasi secara sendiri atau bersama-sama berdasarkan kesepakatannya dengan Usaha Besar Menengah dalam pendirian perusahaan penanaman modal, dengan perimbangan pemilikan saham 60 \% dikuasai Usaha Kecil atau Koperasi dan 40 \% dikuasai oleh Usaha Besar Menengah. Pengelolaan perusahaan pada tahap pertama ditangani oleh Pengusaha Besar Menengah secara bersama-sama dengan Pengusaha Kecil atau Koperasi, dan kemudian secara bertahap paling lambat 10 tahun setelah berproduksi komersil pengelolaan perusahaan akan diserahkan kepada Pengusaha Kecil dan atau Koperasi. ${ }^{11}$

Prinsip usaha bersama yang berbentuk kemitraan tersebut, kemudian dikembangkan lebih lanjut dalam Kebijaksanaan Penanaman Modal. Bentuk kemitraan dapat berupa: Pola Penyertaan Saham, Pola Inti Plasma, Pola Subkontrak, Pola Dagang Umum, Pola Keagenan dan Waralaba. ${ }^{12}$

Kemitraan merupakan bagian dari tanggungjawab sosial perusahaan terhadap lingkungannya sesuai dengan konsep manajemen berdasarkan sasaran

\footnotetext{
${ }^{11}$ Keputusan Bersama Menteri Koperasi dan Pembinaan Pengusaha Kecil dan Menteri Negara Penggerak Dana Investasi/Ketua Badan Koordinasi Penanaman Modal Nomor 01/SKB/M/VI/1995 dan Nomor 11/SK/1995 tentang Penanaman Modal Dalam Bidang Usaha Unggulan Melalui Kemitraan Pengusaha Menengah dan Besar Dengan Pengusaha Kecil dan Koperasi.

12 Peraturan Pemerintah Nomor 44 Tahun 1997 tentang Kemitraan
} 
atau partisipatif. Sesuai dengan konsep manajemen partisipatif, perusahaan besar harus juga bertanggungjawab mengembangkan usaha kecil dan masyarakat pelanggannya, karena pada akhirnya hanya konsep kemitraan (partnership) yang dapat menjamin eksistensi perusahaan besar. ${ }^{13}$

Syarat kemitraan diberlakukan terhadap Usaha Besar Menengah; baik dalam rangka Penanaman Modal Asing (PMA) maupun Penanaman Modal Dalam Nnegeri (PMDN) yang melakukan investasi pada bidang-bidang usaha yang sesungguhnya dicadangkan sebagai bidang usaha bagi Usaha Kecil dan Koperasi. ${ }^{14}$ (sebagaimana yang kemudian diatur dalam Kepres 99 Tahun 1998 dan Peraturan Presiden No. 77 Tahun 2007).

Dalam kemitraan tersebut, Usaha Besar Menengah diwajibkan memberikan pembinaan kepada Usaha kecil agar dapat meningkatkan kesempatan berusaha serta kemampuan manajemen dalam satu atau berbagai aspek dibidang produksi dan pengolahan, pemasaran, sumber daya manusia, teknologi, penyediaan bahan baku, pengelolaan usaha dan pendanaan. Kemitraan yang dilaksanakan melalui penyertaan modal (equity), sekurang-kurangnya $20 \%$ saham pendirian dikuasai oleh Usaha Kecil, yang kemudian harus ditingkatkan secara bertahap. Bentukbentuk kemitraan terdiri dari: ${ }^{15}$ Pola Inti-Plasma, Pola Subkontrak, Pola Perdagangan Umum dan Keagenan, serta Waralaba

Pada bentuk kemitraan dengan Pola Inti Plasma, Usaha Besar dan atau Menengah, berkedudukan sebagai Inti dan berkewajiban membina serta mengembangkan Usaha Kecil yang menjadi plasmanya dalam hal penyediaan dan penyiapan lahan; penyediaan sarana produksi; pemberian bimbingan teknis manajemen usaha dan produksi; perolehan, penguasaan dan peningkatan teknologi yang diperlukan; pembiayaan; membeli dan memasarkan hasil produk.

Kemitraan dengan pola Inti-Plasma tersebut, mengarahkan perilaku Usaha Besar Menengah (sebagai Perusahaan Inti), untuk memberikan bantuan permodalan

\footnotetext{
${ }^{13}$ Nabila Ghassani, "Kemitraan Pengembangan UMKM”, Jurnal Kebijakan dan Manajemen Publik Universitas Airlangga, Volume 3, Nomor 2, Mei-Agustus 2015, hlm. 145.

${ }^{14}$ Keputusan Presiden RI Nomor 99 Tahun 1998 dan Nmor 77 Tahun 2007 tentang Bidang/Jenis Usaha Yang Dicadangkan Untuk Usaha Kecil Dan Bidang/Jenis Usaha Yang Terbuka Untuk Usaha Menengah Atau Usaha Besar Dengan Syarat Kemitraan

15 Undang-Undang Nomor 9 Tahun 1995 tentang Usaha Kecil dan Peraturan Pemerintah Nomor 44 Tahun 1997 tentang Kemitraan
} 
(sarana produksi dan pembiayaan), alih teknologi (teknologi produk/budi daya maupun manajemen) dan akses pasar terhadap Usaha Kecil (sebagai Plasma). Teknologi akan dapat membantu perusahaan untuk mendapatkan kompetensi yang memungkinkan perusahaan untuk menghasilkan produk yang lebih baik. ${ }^{16}$

\section{Praktek Kemitraan Usaha Subsektor Perkebunan dalam Penanaman Modal di Provinsi Bengkulu Era Orde Baru}

Praktek kemitraan dalam Penanaman Modal pada subsektor perkebunan di Indonesia, sudah diperkenalkan sejak 1976, dengan pola Nucleus Estate and Smallhorder (NES), melalui proyek perkebunan bantuan Bank Dunia. Konsep NES ini diperkenalkan oleh Commonwealth Development (CDC) yaitu proyek perkebunan dengan model Inti-Rakyat atau Inti-Plasma, yang kemudian diterapkan oleh Bank Dunia. Di Indonesia, konsep ini kemudian sering disebut dengan Pola Perusahaan Inti Rakyat (PIR-Bun). ${ }^{17}$

Keterkaitan Bank Dunia terhadap diterapkannya Konsep NES dalam usaha Perkebunan di Indonesia, tidak terlepas dari dianutnya model pembangunan ekonomi di Indonesia yang didasarkan pada pertumbuhan. Model pembangunan berdasarkan pertumbuhan, mengasumsikan bahwa pertumbuhan ekonomi harus dilakukan dengan meningkatkan investasi, dan untuk pembiayaan investasi tersebut, Indonesia harus mencari dukungan modal yang besar dari Modal Swasta Asing (melalui PMA) dan hutang luar negeri (melalui lembaga-lembaga keuangan internasional). ${ }^{18}$ Sejak lahirnya Pemerintahan Orde Baru, demi kepentingan rehabilitasi dan pembangunan ekonomi, Pemerintah mulai mencari dukungan dana dari negara-negara Barat, Amerika Serikat dan Jepang. ${ }^{19}$

IMF mulai terlibat lagi di Indonesia sejak Orde Baru 1967; setelah sempat terhenti di ahkir Orde Lama. ${ }^{20}$ Di dalamnya terdapat lembaga-lembaga keuangan

${ }^{16}$ Heru Sulistyo dan Ardian Adiatma, "Model Optimalisasi Kemitraan UKM (Usaha Kecil Menengah) dan BUMN (Badan Usaha Milik Pemerintah) Melalui Program Kemitraan dan Bina Lingkungan (PKBL) Untuk Meningkatkan Kinerja UKM", Jurnal Riptek Bappeda Kota Jakarta, Vol 5 No 11, 2011, hlm. 27

17 Amestina Matualage, dkk, "Pengelolaan Kebun Kelapa Sawit Dalam Pola Kemitraan Inti Plasma PTPN II Prafi Dengan Petani Suku Arfak Di Manokwari Papua Barat”, JSEP Vol. 12 No 1 Maret 2019, hlm. 20.

18 The Worl Bank, https://www.worldbank.org/in/news/feature/2018/10/02/indonesia-and-the-worldbank-partners-through-time

${ }^{19}$ Indonesia Investment, https://www.indonesia-investments.com/id/budaya/ekonomi/keajaiban-ordebaru/item247?

${ }^{20}$ Iswara N Raditya, 2018, "Indonesia dan IMF: Bercerai Karena PKI, Mesra Lagi Berkat Soeharto", ttps://tirto.id/c6bd 
bilateral antar negara maupun lembaga keuangan multilateral; seperti Bank Dunia dan ADB. Selanjutnya, Inter Governmental Group on Indonesia (IGGI) yang dikoordinir oleh Belanda, memberikan pinjaman keuangan setiap tahun kepada Indonesia. Akan tetapi, IGGI tersebut bubar pada 1992; karena Belanda membekukan bantuan keuangan kepada Indonesia dikaitkan dengan peristiwa pembunuhan massal masyarakat Timor Timur di Santa Cruz Dili, Pemerintah Indonesia meminta agar IGGI bubar. Setelah IGGI bubar, Bank Dunia membantu Indonesia Pemerintah Indonesia untuk membentuk Consultative Group on Indonesia (CGI) yang memberikan pinjaman keuangan setiap tahunnya kepada Indonesia. ${ }^{21}$

Pada 1973, Bank Dunia mulai memberikan pinjaman untuk mengembangkan subsektor perkebunan rakyat di Indonesia, terutama untuk budidaya tiga komoditas ekspor utama, yaitu karet, Teh dan kelapa sawit. Pembangunan perkebunan meliputi perkebunan yang sudah ada dan membuka areal perkebunan baru. NES atau PIR-Bun, diperkenalkan pertama kali di Indonesia atas usul Bank Dunia. Proyek pertama subsektor perkebunan dengan pola NES I, yang dibiayai dari pinjaman Bank Dunia, diuji cobakan pelaksanaannya di Sumatera Selatan dan Daerah Istimewa Aceh 1976. Kemudian menyusul NES II di Riau dan Jambi.22 Sejak itu, perkebunan dengan pola PIR terus berkembang; baik yang dibiayai dari pinjaman Bank Dunia maupun dari Lembaga-lembaga keuangan Internasional lainnya. ${ }^{23}$

Pada 1986, berdasarkan lokasi sudah terdapat 29 proyek PIR-Bun 7 diantaranya berupa proyek NES yang dibiayai oleh Bank Dunia. Sampai 1989, sudah tercatat 80 proyek PIR yang telah direalisasikan di Indonesia, dengan luas mencapai 481.847 hektar, meliputi 7 jenis budidaya komoditas; yaitu : Kepala Sawit, Karet, Kakao (coklat), Kelapa Hybrida, Teh, Tebu (gula) dan Kapas. ${ }^{24}$

Pada kurun waktu yang lama, sejak proyek NES 1976 sampai munculnya saran IMF agar Indonesia melakukan penyesuaian struktural dalam penyelesaian hutang

\footnotetext{
${ }^{21}$ M Faisal, 2018, "IGGI dan Asal-Usul Utang Luar Negeri Indonesia", https://tirto.id/cEW3

22 Badrun, M, Pelaksanaan Pola PIR Tonggak Perubahan: Melalui PIR Kelapa Sawit Membangun Negeri. Direktorat Jenderal Perkebunan, Kementerian Pertanian Republik Indonesia, Jakarta. 2010, hlm. 71-94.

${ }^{23}$ Instruksi Presiden Nomor 1 Tahun 1986 tentang Pengembangan Perkebunan Dengan Pola Perusahaan Inti Rakyat Yang Dikaitkan Dengan Program Transmigrasi, dan Keputusan Menteri Pertanian Nomor .333/KPTS/KB/510/ 6/1986 tentang Tata Cara Pelaksanaan Pengembangan Perkebunan Dengan Pola Pir - Trans

${ }^{24}$ Joko Waluyo, Perusahaan Inti Rakyat Perkebunan, dalam Sandra Kartika dan Candra Gautama (Penyunting), Menggugat Posisi Masyarakat Adat Terhadap Negara, Lembaga Studi Pers dan Pembangunan, Jakarta, 1999.
} 
luar negerinya, yaitu dengan mengurangi peran negara dalam pembangunan ekonomi; yang kemudian ditandai oleh munculnya Peraturan Pemerintah Nomor 20 Tahun 1994; yang bertindak sebagai Perusahaan Inti dalam proyek perkebunan dengan Pola PIR-Bun adalah Perusahaan Negara/PT Perkebunan (PTP). Kemudian sejak tahun 1995, Perusahaan Inti mulai dilakukan oleh swasta.

Hingga tahun 1996, terdapat 86 proyek yang dikelola oleh Perusahaan Negara, dengan luas areal perkebunan Plasma 72,25 \% (444.732 hektar) dan areal Perusahaan Inti 27,25\% (170.841 hektar), yang tersebar di 20 provinsi di Indonesia; tidak termasuk DIY, DKI, NTT, NTB, Bali, Sulawesi Utara dan Timor Timur. ${ }^{25}$

Kemitraan dengan pola PIR, mulai 1995,26 dan sebelum 1997, memperlihatkan pemberian posisi Perusahaan Besar dan Menengah terhadap Usaha Kecil dalam bererapa variasi. Kedudukan Perusahaan Besar Menengah sebagai Perusahaan Inti, yaitu perusahaan yang bermitra dengan Usaha Kecil sebagai Plasma dalam rangka pola PIR dapat berkedudukan: Pertama sebagai Perusahaan Pembina, yaitu menyediakan lahan/sarana produksi, memberikan bimbingan teknis dan manajemen, menampung dan mengolah hasil produksi plasma, mengusahakan kredit dan menyediakan sarana produksi atau budidaya. Kedua : Perusahaan Pengelola adalah Perusahaan Inti yang hanya memberikan bimbingan teknis dan manajemen, menampung, mengolah, memasarkan hasil produksi Plasma serta mengusahakan kredit dan menyediakan sarana produksi. Ketiga : Perusahaan Penghela, yaitu Perusahaan Inti yang hanya memberikan bimbingan teknis dan manajemen kepada Plasma serta menampung, menangani (handling) dan mengolah serta memasarkan hasil produksi Plasma. Keempat : Bapak Angkat adalah Perusahaan yang tidak mempunyai keterkaitan Usaha dengan usaha Anak Angkat, yang memberikan bimbingan manajemen, membantu memasarkan hasil, serta membantu mengusahakan kredit atau menyediakan sarana produksi bagi Anak Angkat. Hubungan kemitraan pada periode ini, harus dibuat oleh para pihak diketahui oleh Gubernur Kepala Daerah Tingkat I atau Bupati Kepala Daerah Tingkat II.

\footnotetext{
${ }^{25}$ Diolah dari Keputusan Menteri Pertanian Nomor 819/KPTS/KB.510/11/1996 tentang Penugasan PT Perkebunan Nusantara Dalam Pelaksanaan Proyek PIR Perkebunan. Pola PIR.

${ }^{26}$ Kepmentan Nomor 509/KPTS/KB.12/7/1995 tentang Pedoman Kemitraan Usaha Pertanian Dengan
} 
Sebaran Perkebunan di Indonesia dengan Pola PIR-Bun yang dikelola oleh Perusahaan Negara/PTP hingga tahun 1996, Perkebunan Karet, Kelapa Sawit dan Kelapa Hybrida seperti pada Tabel 1.

Tabel 1: Sebaran Lokasi PIR-Bun Karet, Kelapa Sawit dan Kelapa Hybrida

\begin{tabular}{|c|c|c|c|c|c|c|c|}
\hline \multicolumn{2}{|c|}{ Lokasi } & \multicolumn{2}{|c|}{ PIR-Bun Karet } & \multicolumn{2}{|c|}{$\begin{array}{c}\text { PIR-Bun Kelapa } \\
\text { Sawit }\end{array}$} & \multicolumn{2}{|c|}{$\begin{array}{c}\text { PIR-Bun Kepala } \\
\text { Hybrida }\end{array}$} \\
\hline Pulau & Provinsi & Luas (Ha) & Persen & Luas (Ha) & Persen & $\begin{array}{l}\text { Luas } \\
(\mathrm{Ha})\end{array}$ & Persen \\
\hline Jawa & Jawa Barat & 27.940 & 9,36 & 12.000 & 5,23 & 21.443 & 68,1 \\
\hline Maluku & Maluku & 1.500 & 0,5 & - & - & - & - \\
\hline \multirow[t]{2}{*}{ Sulawesi } & $\begin{array}{l}\text { Sulawesi } \\
\text { Tengah }\end{array}$ & 4.000 & 1,34 & - & - & - & - \\
\hline & $\begin{array}{l}\text { Sulawesi } \\
\text { Selatan }\end{array}$ & - & - & 9.000 & 3,92 & - & - \\
\hline Irian & Irian Jaya & - & - & 15.400 & 6,71 & - & - \\
\hline \multirow[t]{4}{*}{ Kalimantan } & $\begin{array}{l}\text { Kalimantan } \\
\text { Barat }\end{array}$ & 28.000 & 39,8 & 19.000 & 8,28 & - & - \\
\hline & $\begin{array}{l}\text { Kalimantan } \\
\text { Selatan }\end{array}$ & 58.500 & & - & - & - & - \\
\hline & $\begin{array}{l}\text { Kalimantan } \\
\text { Timur }\end{array}$ & 16.000 & & - & - & 10.044 & 31,9 \\
\hline & $\begin{array}{l}\text { Kalimantan } \\
\text { Tengah }\end{array}$ & 16.500 & & - & - & - & - \\
\hline \multirow[t]{9}{*}{ Sumatera } & DI Aceh & 7.000 & & 20.374 & & - & - \\
\hline & $\begin{array}{l}\text { Sumatera } \\
\text { Utara }\end{array}$ & 11.000 & & 32.406 & & - & - \\
\hline & Riau & 17.900 & & 65.550 & & - & - \\
\hline & Sumatera Barat & 14.000 & 49,18 & 6.000 & 75,85 & - & - \\
\hline & Jambi & 41.300 & & 6.000 & & - & - \\
\hline & $\begin{array}{l}\text { Sumatera } \\
\text { Selatan }\end{array}$ & 26.183 & & 29.630 & & - & - \\
\hline & Lampung & 8.650 & & 6.000 & & - & - \\
\hline & Bengkulu & 21.500 & & 8.000 & & - & - \\
\hline & amlah & 299,973 & 100 & 229.360 & 100 & 31.487 & 100 \\
\hline Sumber: D & dari & Keputusa & & Menteri & Pertan & ian & Nomor \\
\hline
\end{tabular}

Diantara Usaha Besar yang berkedudukan sebagai Perusahaan Inti adalah PT. Perkebunan Nusantara (BUMN), yang pada saat tersebut, mengusahakan Perkebunan Karet (milik Perusahaan Inti seluas 7000 hektar dan milik Petani Plasma seluas 14.500 hektar). Selain itu, PT. Perkebunan Nusantara, juga 
mengusahakan Perkebunan Kelapa Sawit (milik Perusahaan Inti seluas 2000 hektar, dan milik Petani Plasma seluas 6000 hektar).

Kegiatan yang dilakukan oleh Perusahaan Inti dalam rangka Pelaksanaan kemitraan pola PIR, dapat dikelompokkan dalam empat tahapan. Pertama, merupakan tahapan persiapan; yang meliputi pengurusan perizinan, penyediaan lahan, mulai dari peninjauan lokasi, studi kelayakan, pendataan calon peserta Plasma, penyusunan rencana proyek, pengaturan dana, hingga pembukaan lahan, pembibitan dan pengolahan lahan hingga siap untuk ditanami. Kedua, pembangunan fisik kebun; mulai dari penanaman, pemeliharaan, sampai tanaman tersebut siap berproduksi, serta penyiapan pemukiman untuk para Petani Plasma. Ketiga, setelah tanaman perkebunan siap berproduksi komersil, pemilikan kebun yang telah dipersiapkan untuk Petani Plasma diserahkan kepada pemiliknya, termasuk lahan pangan, rumah pemukiman dan lahan pekarangan, serta pengalihan kredit kepada para peserta. Pada tahap inilah, perjanjian kemitraan dibuat dan ditanda tangani oleh Perusahaan Inti dengan para petani plasma. Keempat, merupakan tahap pembinaan serta tahap pembayaran kembali kredit oleh Petani Plasma. ${ }^{27}$

Penelitian dilakukan terhadap 15 orang Petani di wilayah studi, ${ }^{28}$ yang telah menjadi Plasma sejak tahun 1987, sekarang Tanaman Sawit yang merupakan kebun plasma pertama sudah diremajakan. Pada masa terjadinya krisis ekonomi lalu, penghasilan mereka meningkat dikarenakan harga Tandan Buah Segar (TBS) mengalami kenaikan. Selama 10 tahun pertama menjadi Petani Plasma, sejak 1987 hingga 1997, diperoleh informasi tentang hubungan kemitraan yang mereka alami, seperti pada Tabel 2 di bawah ini.

Tabel 2 : Informasi Responden

\begin{tabular}{lllll}
\hline Kriteria Informasi & & \multicolumn{1}{c}{ Informasi } & \multicolumn{2}{l}{ Jawaban Informan } \\
\hline Perjanjian & 1. & Dijelaskan Terlebih dahulu & 1 & $6,67 \%$ \\
& 2. & Langsung Tanda Tangan & 14 & $93,33 \%$ \\
Perolehan Kebun & 1. & Dengan membeli ke PTPN & - & - \\
& 2. & Menerima Pemberian dari PTPN & 12 & $80 \%$ \\
& 3. & Membeli dari Petani lain & 3 & $20 \%$ \\
\hline
\end{tabular}

27 Apriansyah, Staf Manajer Unit Talo Pino, PT. Perkebunan Nusantara VII, Wawancara Pribadi, 8 November 2020

28 Amri, Danil, Irwadi, Padli, Kurnia, Mardi, Masri, Nopri, Nanang, Pardi, Parman, Pasiri, Raran, Tasriman, dan Yamardi, Petani Plasma, Wawancara Pribadi, 10-31 Okrober 2020. 


\begin{tabular}{lllll}
\hline Pelatihan & 1. & Cara penyiangan dan pemupukan & 15 & $100 \%$ \\
& 2. & Pemanenan dan Pasca Panen & 15 & $100 \%$ \\
Penjualan Hasil & 3. & Manajemen Keuangan & - & - \\
& 1. & Wajib dijual ke PTPN & 15 & $100 \%$ \\
Harga Penjualan & 2. & Boleh di jual ke Pihak ketiga & - & - \\
& 1. & Ditentukan oleh PTPN & 15 & $100 \%$ \\
& 2. & Sesuai dengan harga ditempat lain & - & - \\
Penghasilan & 3. & Sering lebih rendah dari tempat lain & 15 & $100 \%$ \\
& 1. & Bisa menabung & 3 & $20 \%$ \\
Lain-lain & 2. Cukup untuk biaya hidup sehari & 12 & $80 \%$ \\
& 1. & Kalau tidak dipupuk, buah sangat & 15 & $100 \%$ \\
& 2. & Masih memiliki Usaha lain & 15 & $100 \%$ \\
\hline
\end{tabular}

Sumber : Diinterpretasi dari Informasi Penelitian

Hubungan Kemitraan antara PT. Perkebunan Nusantara dengan Petani Plasma, dapat dinterpretasikan maknanya untuk menggambarkan konstruksi hukum hubungan kemitraan di wilayah studi, seperti dalam Tabel 3 di bawah ini.

Tabel 3 Konstruksi Hukum Hubungan Kemitraan

\begin{tabular}{|c|c|c|}
\hline No & Karakter Hubngan Kemitraan & Konstruksi Hukum \\
\hline 1 & $\begin{array}{l}\text { Permodalan untuk Petani Plsdama seluruhnya } \\
\text { diusahakan oleh Perusahaan Inti }\end{array}$ & $\begin{array}{l}\text { Petani Plasma tidak } \\
\text { memperoleh bantuan }\end{array}$ \\
\hline 2 & $\begin{array}{l}\text { Perusahaan Inti bertindak sebagai Penjamin } \\
\text { Pinjaman Modal }\end{array}$ & $\begin{array}{ll}\text { Modal dari } \\
\text { Pemerintah }\end{array}$ \\
\hline 3 & $\begin{array}{l}\text { Perjanjian Kemitraan berupa Perjanjian standar } \\
\text { yang disiapkan oleh Perusahaan Inti dan ditanda } \\
\text { tangani oleh Para Pihak. }\end{array}$ & $\begin{array}{l}\text { Petani di Subordiansi } \\
\text { Perusahaan Inti }\end{array}$ \\
\hline 4 & $\begin{array}{l}\text { Petani Plasama Wajib menjual seluruh produk } \\
\text { kepada Perusahaan Inti }\end{array}$ & Monopoli \\
\hline 5 & $\begin{array}{l}\text { Petani Plasma sering merugi, karena harga Tandan } \\
\text { Buah Segar (TBS) ditetapkan sepihak oleh } \\
\text { Perusahaan Inti berdasarkan patokan harga yang } \\
\text { ditetapkan oleh suatu Tim bentukan Pemerintah } \\
\text { (Gubernur), yang keanggotaannya terdiri dari unsur } \\
\text { Pemda Tingkat I, unsur Dinas Perkebunan Daerah } \\
\text { Tingkat I, unsur Perusahaan Inti, dan unsur Asosiasi } \\
\text { Petani Plasma. }\end{array}$ & $\begin{array}{l}\text { Pelaksanaan Kemitra- } \\
\text { an tidak diawasi oleh } \\
\text { Pemerintah; Tidak } \\
\text { mencerminkan } \\
\text { prinsip kemitraan }\end{array}$ \\
\hline 6 & $\begin{array}{l}\text { Pendidikan dan latihan, dilakukan oleh tenaga } \\
\text { teknis dari Dinas Perkebunan setempat, agar Petani } \\
\text { Plasma dapat menggunakan teknologi pengelolaan } \\
\text { perkebunan (penyiangan, pemupukan, } \\
\text { pemberantasan hama dan pemanenan) }\end{array}$ & $\begin{array}{l}\text { Petani Plasma Tidak } \\
\text { memperoleh } \\
\text { Pembina- an yang } \\
\text { memadai }\end{array}$ \\
\hline
\end{tabular}




\begin{tabular}{lllll}
\hline 7 & Bibit tanaman & yang dibudidayakan, & Ketergantungan \\
produktivitasnya sangat tergantung pada & teknologi \\
penggunaan jenis pupuk kimia tertentu; yang & \\
semakin tahun kebutuhannya semakin meningkat. & \\
\hline
\end{tabular}

Sumber : Diinterpretasi dari Informasi Penelitian

Berdasarkan Tabel 3 di atas, praktek kemitraan antara Perusahaan Inti dengan Petani Plasma, memposisikan Petani Plasama berada dibawah Subordinasi Perusahaan Inti. Posisi Subordinasi itu, diawali oleh kebijakan kredit yaang lebih berpihak kepada Usaha Besar, Perjanjian Standar yang dibuat oleh Perusahaan Inti, dan pelaksanaannya tidak mendapat pengawasan oleh Pemerintah atau Pemerintah Daerah. Petani Plasma juga kurang memperoleh Pembinaan, sehingga secara keseluruhan karakter hubungan kemitraan pada era Orde Baru bersifat ekspolitatif.

\section{Analisis Akar Permasalahan Kemitraan}

Model kemitraan Perusahaan Inti-Plasma pada dasarnya merupakan upaya menggabungkan dua jenis sistem ekonomi, yaitu sistem ekonomi modern dan sistem ekonomi subsisten. Karena itu, maka kemitraan merupakan kebijakan ekonomi dualistik, disatu sisi ingin mengubah sistem perekonomian menjadi modern, tetapi dengan tetap berupaya mempertahankan ekonomi tradisional. ${ }^{29}$

Perusahaan-perusahaan Swasta atau Badan Usaha Milik Negara (BUMN), yang menjadi Perusahaan Inti, merupakan perusahaan yang berorientasi pada budaya ekonomi modern, baik dari aspek manajemen maupun aspek tujuannya. Sebagai Perusahaan Inti, perusahaan-perusahaan tersebut; sebagaimana layaknya perusahaan modern telah memiliki budaya kerja tertentu dan tujuan perusahaan adalah optimalisasi pencapaian keuntungan. Teknologi yang mereka pergunakan; baik teknologi manajemen maupun teknologi produksi serta pemasaran sudah sangat maju. Mereka melakukan usaha dengan terorganisisir secara baik dan efektif. ${ }^{30}$

${ }^{29}$ M. Dawam Rahardjo. “Menuju Sistem Perekonomian Indonesia”, Jurnal Unisia, Vol. XXXII No. 72 Desember 2009, hlm, 112

30 Ibid 
Sebaliknya, perusahaan Plasma sebagai pelaku ekonomi subsisten, memiliki budaya ekonomi yang sangat berbeda. Para Petani Plasma di wilayah studi, melakukan usaha secara perorangan, menggunakan tenaga kerja dari kalangan keluarga sendiri, mempunyai modal terbatas dan umumnya berupa lahan pertanian, dan tujuan usahanya masih berorientasi pada upaya pemenuhan kebutuhan jangka pendek, dengan tingkat teknologi yang rendah. Kemampuan manajemen rendah, dan jangkauan produknya hanya terbatas dalam pasar lokal.

Upaya Pemerintah Indonesia untuk menggabungkan kedua sistem ekonomi tersebut melalui konsep kemitraan dengan mengkaitkan kebersamaan antara industri hulu dan industri hilir, ternyata dalam pelaksanaannya di wilayah studi, masih terlihat sulit untuk menjadi kenyataan. Karakter hubungan ekonomi ketergantungan dan eksploitatif masih jelas terlihat mewarnai hubungan kemitraan tersebut.

Jurang budaya ekonomi yang lebar antara Perusahaan Inti dan Petani Plasma tampaknya menjadi penyebab munculnya hubungan yang bertentangan dengan prinsip kemitraan; yang mengasumsikan bahwa perusahaan yang kuat diharapkan akan membantu perusahaan yang lemah dan perusahaan yang lemah harus secara ikhlas menerima bantuan dan menjalin kerja sama dengan Perusahaan yang kuat, sehingga terjalin hubungan yang interdepensi. Jurang budaya yang lebar antara Perusahaan Inti dan Petani Plasma tersebut, kemudian ditopang pula oleh kebijaksanaan Kemitraan yang memposisikan Petani Plasma dalam subordinasi Perusahaan Inti; ${ }^{31}$ baik dalam penyediaan kredit investasi, teknologi dan pemasaran produk. Keadaan yang demikian telah menjadikan Petani Plasma mirip dengan tenaga buruh perkebunan dari Perusahaan Inti. Petani Plasma, sama sekali tidak memiliki independensi, tidak mempunyai kebebasan (kemandirian), melainkan dependensi terhadap Perusahaan Inti. Suasana ketergantungan Petani Plasma terhadap Perusahaan Inti tersebut, menimbulkan ekses munculnya hubungan kemitraan yang eksploitatif.

Model kebijaksanaan ekonomi dualistik melalui konsep kemitraan, memang sesuai dengan arahan nilai-nilai konstitusional, maupun nilai-nilai masyarakat

\footnotetext{
31 Ami Suswandi Putra, "Pola Kemitraan Pariwisata dalam Manajemen Atraksi Desa Wisata Pampang Kota Samarinda”, Jurnal Nasional Pariwisata, Vol 5 No 3, Desember 2013, hlm. 190.
} 
yang masih bercorak tradisional. Karena itu, upaya yang masih harus dilakukan adalah menciptakan agar persandingan antara pelaku ekonomi subsisten dengan pelaku ekonomi modern tersebut, dapat terbebas dari pola hubungan yang ekploitatif. Peran Pemerintah Era Reformasi untuk mereform kebijakan kemitraan, melakukan pembinaan, perlindungan dan pemberdayaan terhadap Usaha Mikro, Usaha Kecil dan Usaha Menengah serta melakukan pengawasan terhadap pelaksanaan kemitraan. Merupakan upaya yang sangat diperlukan untuk mengatasi hubungan kemitraan yang ekspoitatif pada Era Pemerintahan Orde Baru.

\section{Rekonstruksi Kebijakan Kemitraan Era Reformasi}

Reformasi kebijakan kemitraan di Era Reformasi, dimulai dengan pembentukan Undang-Undang Nomor 25 Tahun 2007 tentang Penanaman Modal, menggantikan Undang-Undang Nomor Nomor 1 Tahun 1967 tentang Penanaman Modal Asing; sebagaimana telah diubah dengan Undang-Undang Nomor 11 Tahun 1970 tentang Perubahan dan Tambahan Undang-Undang Nomor 1 Tahun 1967 tentang Penanaman Modal Asing, dan mencabut UndangUndang Nomor 6 Tahun 1968 tentang Penanaman Modal Dalam Negeri; sebagaimana telah diubah dengan Undang-Undang Nomor 12 Tahun 1970 tentang Perubahan dan Tambahan Undang-Undang Nomor 6 Tahun 1968 tentang Penanaman Modal Dalam Negeri.

Kebijakan penanaman modal di Era Reformasi dilalukan dengan memberikan tugas kepada Pemerintah untuk melakukan pembinaan dan pengembangan usaha mikro, kecil, menengah, dan koperasi, melalui program kemitraan, peningkatan daya saing, pemberian dorongan inovasi dan perluasan pasar, serta penyebaran informasi yang seluas-luasnya. ${ }^{32}$ Kemudian, narasi "pembinaan dan pengembangan", diubah menjadi "pelindungan dan pemberdayaan, berupa pembinaan dan pengembangan", serta menambahkan program pelatihan sumber daya manusia dalam pembinaan dan pengembangan. ${ }^{33}$

Dalam kebijakan kemitraan ditentukan bahwa : (1) Perjanjian kemitraan dituangkan dalam perjanjian tertulis yang sekurang-kurangnya mengatur

\footnotetext{
32 Pasal 13 ayat (2) Undang-Undang Nomor 25 Tahun 2007 tentang Penanaman Modal

${ }^{33}$ Undang-Undang Nomor 11 Tahun 2020 tentang Cipta Kerja.
} 
kegiatan usaha, hak dan kewajiban masing-masing pihak, bentuk pengembangan, jangka waktu, dan penyelesaian perselisihan; (2) Perjanjian kemitraan dilaporkan kepada pihak yang berwenang sesuai dengan ketentuan peraturan perundangundangan; (3) Perjanjian kemitraan tidak boleh bertentangan dengan prinsip dasar kemandirian Usaha Mikro, Kecil, dan Menengah serta tidak menciptakan ketergantungan Usaha Mikro, Kecil, dan Menengah terhadap Usaha Besar; ${ }^{34}$ dan (4) Untuk memantau pelaksanaan kemitraan Menteri dapat membentuk lembaga koordinasi kemitraan usaha nasional dan daerah. ${ }^{35}$

Dalam melaksanakan kemitraan, para pihak mempunyai kedudukan hukum yang setara dan terhadap mereka berlaku hukum Indonesia, dan diawasi secara tertib dan teratur oleh lembaga yang dibentuk dan bertugas untuk mengawasi persaingan usaha sebagaimana diatur dalam peraturan perundang-undangan. ${ }^{36}$ Peran Pemerintah dan Pemerintah Daerah dalam pemberdayaan UMK-M, berkaitan dengan Pengembangan Usaha, Kemitraan, Perizinan, serta Koordinasi dan Pengendalian. ${ }^{37}$

Perkembangan terakhir dari kebijakan Pemerintah di Era Reformasi berdasarkan Undang-Undang Cipta Kerja, ${ }^{38}$ lingkup pengaturannya tidak hanya mengenai UMK-M tetapi juga Koperasi. Kemudian, substansinya bukan hanya menyangkut Program Pemberdayaan, tetapi juga menyangkut Kemudahan dan Perlindungan terhadap Koperasi dan UMK-M. ${ }^{39}$

Kemudahan bagi Koperasi diberikan dalam bentuk pendampingan dari Pemerintah atau Dinas Koperasi dalam pendirian dan perizinan Koperasi. Perlindungan diberikan oleh Pemerintah atau Pemerintah Daerah dengan menetapkan bidang usaha yang hanya diusahakan oleh Koperasi dan pada Bidang Usaha yang telah berhasil diusahakan oleh Badan Usaha lain. Terhadap

\footnotetext{
34 Pasal 34 Peraturan Pemerintah Nomor 17 Tahun 2013 tentang Pelaksanaan Undang-Undang Nomor 20 Tahun 2008 Tentang Usaha Mikro, Kecil dan Menengah.

35 Pasal 26 Undang-Undang Nomor 20 Tahun 2008 tentang Usaha Mikro, Kecil dan Menengah dan PP Nomor 17 Tahun 2013 Tentang Pelaksanaan Undang-Undang Nomor 20 Tahun 2008 tentang Usaha Mikro, Kecil dan Menengah Menengah.

36 Pasal 36 ayat (1) dan (2) Undang-Undang Nomor 20 Tahun 2008 tentang Usaha Mikro, Kecil dan

37 Peraturan Pemerintah Nomor 17 Tahun 2013 tentang Pelaksanaan Undang-Undang Nomor 20 Tahun 2008 Tentang Usaha Mikro, Kecil dan Menengah.

38 Undang-Undang Nomor 11 Tahun 2020 tentang Cipta Kerja

39 Peraturan Pemerintah Nomor 7 Tahun 2021 tentang Kemudahan, Pelindungan, dan Pemberdayaan Koperasi dan Usaha Mikro, Kecil, dan Menengah,
} 
Koperasi yang mengalami kondisi darurat, dilakukan upaya pemulihan melalui restrukturasi kredit; restrukturisasi usaha, bantuan modal dan bantuan lain. Pemberdayaan Koperasi dilakukan oleh Pemerintah atau Pemerintah Daerah terhadap kelembagaan, produksi, pemasaran, keuangan, serta inovasi dan teknologi. Pemberdayaan Koperasi Khusus, diberikan kepada koperasi bidang usaha kelautan dan perikanan, angkutan perairan pelabuhan, kehutanan, perdagangan dan pertanian.

Pengelompokkan UMK-M, didasarkan pada kriteria permodalan atau kriteria hasil penjualan produk tahunan. Diluar tanah dan bangunan tempat usaha: (a). Kelompok Usaha Mikro memiliki modal paling banyak Rp. 1.000.000.000,00, atau memiliki hasil pernjualan paling banyak $\mathrm{Rp}$. 2.000.000.000,00; (b). Kelompok Usaha Kecil memiliki modal diatas Rp. 1.000.000.000,00 sampai paling banyak Rp. 5.000.000.000,00 atau memiliki hasil penjualan di atas Rp. 2.000.000.000,00 sampai Rp. 15.000.000.000,00; dan (c). Kelompok Usaha Menengah memiliki modal di atas Rp. 5.000.000.000,00 sampai paling banyak Rp. 10.000.000.000,00 atau memiliki hasil penjualan diatas Rp. 15.000.000.000,00 sampai Rp. 50.000.000.000,00.40

Kemudahan terhadap UMK-M, diberikan melalui perizinan berbasis risiko oleh lembaga yang mengelola Perizinan Berusaha secara terintegrasi secara elektronik. Perizinan berusaha yang diberikan terhadap UMK-M berupa: (a). Nomor Induk Berusaha untuk kegiatan usaha risiko rendah; (b). Nomor Induk Berusaha dan Sertifikat Standar untuk kegiatan usaha risiko menengah; dan (c). Nomor Induk Berusaha dan Izin untuk kegiatan usaha risiko tinggi. ${ }^{41}$

Perlindungan UMK-M yang diberikan Pemerintah dan Pemerintah Daerah, meliputi: (a). Penyediaan layanan bantuan dan pendampingan hukum oleh Pemerintah atau Pemerintah Daerah, meliputi: penyuluhan hukum, konsultasi hukum, mediasi, penyusunan dokumen hukum, dan pendampingan di luar pengadilan; atau rnemberikan bantuan pembiayaan kepada Usaha Mikro dan Usaha Kecil yang meminta layanan bantuan dan pendanrpingan hukum yang

40 Pasal 35 ayat (3) dan ayat (6) Peraturan Pemerintah Nomor 7 Tahun 2021 tentang Kemudahan, Pelindungan, dan Pemberdayaan Koperasi dan Usaha Mikro, Kecil, dan Menengah

${ }^{41}$ Pasal 37 ayat (2) Peraturan Pemerintah Nomor 7 Tahun 2021 tentang Kemudahan, Pelindungan, dan Pemberdayaan Koperasi dan Usaha Mikro, Kecil, dan Menengah 
disediakan oleh pihak lain; dan (b).Pemulihan UMK-M yang mengalami kondisi darurat melalui restrukturisasi kredit, rekonstruksi usaha, bantuan permodalan, dan atau bantuan bentuk lain.

Pemberdayaan UMK-M dilakukan berdasarkan basis data tunggal, yang dikoordinasikan oleh Kementerian melalui pengumpulan, pemeriksaan dan pengolahan data UMK-M yang disampaikan oleh Kementerian, lembaga NonKementerian dan Pemerintah Daerah. Pemberdayaan dilakukan Pemerintah dan Pemerintah Daerah, melalui: (a). Penyediaan Tempat Promosi dan Pengembangan pada Infrastruktur Publik; (b). Pengelolaan terpadu terhadap kelompok Usaha Mikro dan Usaha Kecil yamg terkait dalam suatu rantai produk umum, ketergantungan atas keterampilan tenaga kerja yang serupa, serta penggunaan teknologi yang serupa dan saling melengkapi secara terintegrasi melalui Koperasi; (c). memfasilitasi Hak Kekayaan Intelektual; (d). Penggunaan barang dan jasa Usaha Mikro, Usaha Kecil dan Koperasi; (e). Pencatatan dan Pembukuan Sistem Aplikasi Laporan Keuangan; (f). Pengalokasian Usaha Bagi Usaha Mikro dan Usaha Kecil; (g). Pemeliharaan terminal; (h). Pengembangan Usaha; (i). Koordinasi dan pengendalian Kemudahan, Perlindungan, dan Pemberdayaan.

Pemerintah di Era Reformasi, menempatkan kemitraan sebagai pola hubungan usaha antara Usaha Besar dan menengah dengan Koperasi, Usaha Mikro dan Usaha Kecil. Pola hubungan kemitraan pola rantai pasok ditambahkan,42 selain pola kemitraan inti-plasma, subkontrak, waralaba, perdagangan umum, distribusi dan keagenan, bagi hasil, kerja sama operasional, usaha patungan (joint venture), dan penyumberluaran (outsourcing). ${ }^{43}$

Koreksi terhadap kebijakan kemitraan Era Orde Baru, sudah dilakukan oleh Pemerintahan era reformasi. Dalam konstruksi baru kebijakan kemitraan ini ditentukan: 44

1. Koperasi, Usaha Mikro, Kecil, dan Menengah diwajibkan memenuhi Perizinan Berusaha berbasis risiko, untuk kepentingan pendataan Pelaku dan Bidang Usaha;

\footnotetext{
42 Pasal 106 ayat (1) Peraturan Pemerintah Nomor 7 Tahun 2021 tentang Kemudahan, Pelindungan, dan Pemberdayaan Koperasi dan Usaha Mikro, Kecil, dan Menengah

43 Pasal 11 ayat (2) Peraturan Pemerintah Nomor 17 Tahun 2013 tentang Pelaksanaan Undang-Undang Nomor 20 Tahun 2008 Tentang Usaha Mikro, Kecil, dan Menengah

${ }^{44}$ Peraturan Pemerintah Nomor 7 Tahun 2021 tentang Kemudahan, Pelindungan, dan Pemberdayaan Koperasi dan Usaha Mikro, Kecil, dan Menengah
} 
2. Pemerintah dan Pemerintah Daerah memberikan kemudahan dalam perizinan Berusaha, perlindungan hukum, dan pemberdayaan terhadap Koperasi, Usaha Mikro, dan Usaha Kecil,

3. Kemitraan antara Usaha Besar dan Menengah dengan Koperasi, Usaha Mikro, dan Usaha Kecil diawasi oleh Komisi Pengawas Persaingan Usaha (KPPU).

\section{Penutup}

Berdasarkan uraian yang telah dikemukakan dalam seluruh uraian di atas, maka dapat disimpulkan, sebagai berikut. Pertama, kebijakan Kemitraan Era Orde Baru di Indonesia bukan dimaksudkan untuk menderivasi prinsip usaha bersama dalam Pasal 33 Undang-Undang Dasar 1945, melainkan dalam rangka pelaksasanaan proyek Bank Dunia dan IMF sejak 1976. Kemitraan baru ditetapkan menjadi kebijakan dalam penanaman modal dipenghujung Era Otde Baru 1995. Kedua, praktek Kemitraan usaha Inti-Plasma Subsektor Perkebunan selama masa Orde Baru, menempatkan perusahaan Plasma berada di bawah subordinasi Perusahaan Inti, dan menghasilkan pola hubungan ekonomi yang eksploitatif. Ketiga, rekonstruksi Kebijakan kemitraan Era Reformasi dilakukan dengan memberikan kemudahan, perlindungan hukum, dan pemberdayaan Koperasi, Usaha Mikro, dan Usaha Kecil, serta melakukan pengawasan kemitraan, yang dilakukan secara berkelanjutan.

Berdasarkan simpulan di atas, disarankan agar Pemerintah dan Pemerintah Daerah Era Reformasi saat ini, dapat konsisten melaksanakan kebijakan kemitraan usaha yang telah dibangun, dengan memberikan kemudahan, perlindungan hukum, pemberdayaan Koperasi dan UMK-M, dan melakukan pemantauan dengan teratur terhadap praktek hubungan kemitraan.

\section{Daftar Pustaka}

\section{Buku}

Badrun, M., Pelaksanaan Pola PIR Tonggak Perubahan: Melalui PIR Kelapa Sawit Membangun Negeri, Direktorat Jenderal Perkebunan, Kementerian Pertanian Republik Indonesia, Jakarta, 2010.

Waluyo, Joko, Perusahaan Inti Rakyat Perkebunan, dalam Sandra Kartika dan Candra Gautama (Penyunting), Menggugat Posisi Masyarakat Adat Terhadap Negara, Lembaga Studi Pers dan Pembangunan, Jakarta, 1999. 
Winarno, Budi, Globalisasi E Krisis Demokrasi, PT Buku Kita, Jakarta, 2007.

\section{Jurnal dan Makalah}

Achmad Rudiyanto Afif, "Pola Kemitraan Koperasi Sejahtera Abadi dalam Meningkatkan Keuntungan Petani Cabai", JEJAK (Journal of Economics and Policy) Universitas Negeri Semarang, Vol, 7, No. 2, September, 2014. DOI:http:/ / dx.doi.org/10.15294/jejak.v7i1.3596.

Nabila Ghassani, "Kemitraan Pengembangan UMKM", Jurnal Kebijakan dan Manajemen Publik Universitas Airlangga, Vol. 3, Nomor 2, Mei-Agustus, 2015. http://journal.unair.ac.id/KMP@\%E2\%80\%9Ckemitraanpengembangan-umkm\%E2\%80\%9D-(studi-deskriptif-tentang-kemitraanpt.-pjb-(pembangkit-jawa-bali)-unit-gresik-pengembangan-umkmkabupaten-gresik)-article-9033-media-138-category-8.html

Muslimin Nasution, "Pembangunan Sumberdaya Manusia dan Ekonomi Berbasis Pertanian dan Kelautan Untuk Memperkuat Otonomi Daerah Menuju Masyarakat Madani Indonesia", Makalah Simposium Nasional "Pembangunan SDM, OTDA dan Masyarakat Madani Indonesia", disampaikan pada Forum Mahasiswa Pascasarjana IPB, Bogor, 17 Febuari 2001.

Amestina Matualage, dkk, "Pengelolaan Kebun Kelapa Sawit Dalam Pola Kemitraan Inti Plasma PTPN II Prafi Dengan Petani Suku Arfak Di Manokwari Papua Barat", Jurnal Sosial Ekonomi Pertanian (J-SEP) Universitas Jember Vol. 12 No. 1, Maret, 2019. DOI: https://doi.org/10.19184/jsep.v12i1.6897.

Ami Suswandi Putra, "Pola Kemitraan Pariwisata dalam Manajemen Atraksi Desa Wisata Pampang Kota Samarinda", Jurnal Nasional Pariwisata Universitas Gajah Mada, Vol. 5 No. 3, Desember, 2013. DOI:https:/ / doi.org/10.22146/jnp.669.

M. Dawam Rahardjo, "Menuju Sistem Perekonomian Indonesia", Jurnal Unisia, Vol. XXXII $\quad$ No. $72 \quad$ Desember 2009. https:/ /journal.uii.ac.id/Unisia/article/view/2713/2500.

Heru Sulistyo dan Adiatma, Ardian, "Model Optimalisasi Kemitraan UKM (Usaha Kecil Menengah) dan BUMN (Badan Usaha Milik Pemerintah) Melalui Program Kemitraan dan Bina Lingkungan (PKBL) Untuk Meningkatkan Kinerja UKM", Jurnal Riptek, Vol. 5 No. 11, 2011. http:/ / bappeda.semarangkota.go.id/v2/wp-

content/uploads/2013/12/3.artikel-bappeda2011_HERU_revisi.pdf.

\section{Internet}

M Faisal, 2018, "IGGI dan Asal-Usul Utang Luar Negeri Indonesia", https://tirto.id/cEW3, diakses 8 November 2020. "Indonesia Investment", https:/ / www.indonesiainvestments.com/id/budaya/ekonomi/keajaiban-orde-baru/item247?, diakses 30 November 2020. 
Iswara N Raditya, 2018, "Indonesia dan IMF: Bercerai Karena PKI, Mesra Lagi Berkat Soeharto", https://tirto.id/c6bd, diakses 8 November 2020. "The Worl Bank", https://www.worldbank.org/in/news/feature /2018/10/02/indonesia-and-the-world-bank-partners-through-time, diakses 27 November 2020.

\section{Peraturan Perundang-Undangan:}

Undang-Undang Republik Indonesia Nomor 9 Tahun 1995 tentang Usaha Kecil, Lembaran Negara Republik Indonesia Tahun 1995 Nomor 74, Tambahan Lembaran Negara Republik Indonesia Nomor 3611.

Undang-Undang Republik Indonesia Nomor 25 Tahun 2007 tentang Penanam Modal, Lembaran Negara Republik Indonesia Tahun 2007 Nomor 67, Tambahan Lembaran Negara Republik Indonesia Nomor 4724.

Undang-Undang Republik Indonesia Nomor 20 Tahun 2008 tentang Usaha Mikro, Kecil, Dan Menengah. Lembaran Negara Republik Indonesia Tahun 2008 Nomor 93, Tambahan Lembaran Negara Nomor 4866.

Undang-Undang Nomor 11 Tahun 2020 tentang Cipta Kerja, Lembaran Negara Republik Indonesia Tahun 2020 Nomor 245, Tambahan Lembaran Negara Republik Indonesia Nomor 6573.

Peraturan Pemerintah Republik Indonesia Nomor 44 Tahun 1997 tentang Kemitraan, Lembaran Negara Republik Indonesia Tahun 1997 Nomor 91, Tambahan Lembaran Negara Nomor 3718.

Peraturan Pemerintah Republik Indonesia Nomor 17 Tahun 2013 tentang Pelaksanaan Undang-Undang Nomor 20 Tahun 2008 Tentang Usaha Mikro, Kecil dan Menengah, Lembaran Negara Republik Indonesia Tahun 2013 Nomor 40. Tambahan Lembaran Negara Nomor 5404.

Peraturan Pemerintah Republik Indonesia Nomor 7 Tahun 2021 tentang Kemudahan, Pelindungan, dan Pemberdayaan Koperasi dan Usaha Mikro, Kecil, dan Menengah, Lembaran Negara Republik Indonesia Tahun 2021 Nomor 17, Tambahan Lembaran Negara Nomor 6619.

Keputusan Presiden RI Nomor 99 Tahun 1998 tentang Bidang/Jenis Usaha Yang Dicadangkan Untuk Usaha Kecil Dan Bidang/Jenis Usaha Yang Terbuka Untuk Usaha Menengah Atau Usaha Besar Dengan Syarat Kemitraan. Lembaran Negara Republik Indonesia Tahun 1998 Nomor 112.

Keptusan Presiden RI Nmor 77 Tahun 2007 Daftar Bidang Usaha Yang Tertutup Dan Bidang Usaha Yang Terbuka Dengan Persyaratan Di Bidang Penanaman Modal, Lembaran Negara Republik Indonesia Tahun 2007 Nomor 161.

Instruksi Presiden Nomor 1 Tahun 1986 tentang Pengembangan Perkebunan Dengan Pola Perusahaan Inti Rakyat Yang Dirkaitkan Dengan Program Transmigrasi. 
Keputusan Menteri Pertanian Nomor 853 Tahun 1984 tentang pengembangan perkebunan Kelapa Sawit dan Karet dilakukan dengan pola PIR.

Keputusan Menteri Pertanian Republik Indonesia Nomor 09/KPTS/KB.12/7/1995 tentang Pedoman Kemitraan Usaha Pertanian Dengan Pola PIR.

Keputusan Menteri Pertanian Nomor .333/KPTS/KB/510/ 6/1986 tentang Tata Cara Pelaksanaan Pengembangan Perkebunan Dengan Pola Pir - Trans.

Keputusan Bersama Menteri Koperasi dan Pembinaan Pengusaha Kecil dan Menteri Negara Penggerak Dana Investasi/Ketua Badan Koordinasi Penanaman Modal Nomor 01/SKB/M/VI/1995 dan Nomor 11/SK/1995 tentang Penanaman Modal Dalam Bidang Usaha Unggulan Melalui Kemitraan Pengusaha Menengah dan Besar Dengan Pengusaha Kecil dan Koperasi.

Keputusan Menteri Pertanian Nomor 819/KPTS/KB.510/11/1996 tentang Penugasan PT Perkebunan Nusantara Dalam Pelaksanaan Proyek PIR Perkebunan. 